\title{
Contextual Effect of Village on the Risk of Postpartum Depression after Earthquake in Lombok, Indonesia
}

\author{
Baiq Tuhu Abdiani'), Didik Tamtomo²), Hanung Prasetya ${ }^{3)}$ \\ 1) Masters Program in Public Health, Univeritas Sebelas Maret \\ 2) Faculty of Medicine, Universitas Sebelas Maret \\ 3) School of Health Polytechnics, Ministry of Health Surakarta
}

\begin{abstract}
Background: Postpartum depression is a feeling disorder experienced by the mother after giving birth that can occur at any time within one year. According to the WHO, the post-disaster of most of the affected population have normal psychological reactions and around 15 to $20 \%$ will experience mental disorders that refer to Post Traumatic Stress Disorder (PTSD). 3 to 4\% experience severe disorders such as psychosis, major depression and high anxiety. This study aims to analyze the village contextual influence on postpartum depression post earthquake.

Subjects and Method: This was observational analytic study with cross sectional approach, conducted in 25 villages in East Lombok district, Indonesia in March to April 2019. The total sample of 225 postpartum mothers was selected using stratified random sampling. The dependent variable was postpartum depression. The independent variables were age, parity, education, employment, income, obstetric history, social support, stress coping, government support, the role of health personnel, and the level of loss. The data collection was conducted using questionnaires and analyzed using multilevel multiple logistic regression analysis.

Results: Postpartum depression was affected by age $<20$ or $>35$ years $(\mathrm{b}=1.79 ; 95 \% \mathrm{CI}=2.85$ to $13.37 ; \mathrm{p}=0.001)$, parity $<2$ or $>4(\mathrm{~b}=1.45 ; 95 \% \mathrm{CI}=0.37$ to $2.53 ; \mathrm{p}=0.008)$, high income $(\mathrm{b}=-$ 1.68; CI 95\% $=-2.75$ to $-0.61 ; \mathrm{p}=0.002)$, there was an obstetric history $(\mathrm{b}=1.03 ; \mathrm{CI} 95 \%=-0.03$ to $2.11 ; \mathrm{p}=0.059)$, strong social support $(\mathrm{b}=-1.62 ; 95 \% \mathrm{CI}=-2.76$ to $-0.48 ; \mathrm{p}=0.005$, good coping stress $(b=-3.95 ; 95 \% C I=-5.42$ to $-2.47 ; p<0.001)$, strong government support $(b=-1.26$; $95 \% \mathrm{CI}=-2.34$ to $-0.18 ; \mathrm{p}=0.022)$, the role of health personnel $(\mathrm{b}=-2.06$; CI $95 \%=-3.29$ to $0.83 ; \mathrm{p}=0.001)$, and the rate of loss $(\mathrm{b}=2.69 ; 95 \% \mathrm{CI}=1.46$ to $3.92 ; \mathrm{p}<0.001)$ Postpartum depression was not influenced by higher education $(\mathrm{b}=-0.60 ; 95 \% \mathrm{CI}=-1.63$ to $0.42 ; \mathrm{p}=0.250)$ and low employment $(\mathrm{b}=0.57 ; 95 \% \mathrm{CI}=-0.44$ to $1.59 ; \mathrm{p}=0.272)$. Villages has a contextual influence on postpartum depression after the earthquake (ICC $=8.36 \%$ ).

Conclusion: Age, parity, income, obstetric history, social support, stress coping, government support, the role of health personnel, and the level of loss have an influence on postpartum depression after the earthquake. There is a contextual influence between the villages on average on the incidence of postpartum depression after the earthquake.
\end{abstract}

Keywords: postpartum depression, stress coping, post earthquake, multilevel analysis

\section{Correspondence:}

Baiq Tuhu Abdiani, Public Health Master's Program, Universitas Sebelas Maret. Jl. Ir. Sutami 36 A, Surakarta 57126, Jawa Tengah. Email: tuhuabdiani8@gmail.com Mobile: o81999546500.

\section{BACKGROUND}

Indonesia is a country that has areas prone to natural disasters, namely earthquakes and potential tsunamis (Climatology Meteorology Agency, and Geophysics, 2018). Surveys show that, after a catastrophic event, most of the disaster affected population still have normal psychological reactions, and around $15-20 \%$ will experience mild or moderate mental disorders that refer to PTSD, while 3-4\% will experience severe disorders such as psychosis, depres- 
sion weight and high anxiety (World Health Organization (WHO, 2013).

Study conducted by Ando (2011), stated that mental health problems after the earthquake in Japan in 2011 were found and it showed that depressed conditions were experienced by around $3-43.7 \%$ of earthquake victims.

On August 5, 2018 a 7-magnitude tectonic earthquake occurred on the island of Lombok, Indonesia after a series of earthquakes since the beginning of July 2018 with 6.4 SR caused 555 lives, 1,054 injured and 417,529 people have to be evacuated. In addition, this disaster caused a significant loss of material in terms of population settlements, infrastructure, productive economy, interruption of public services, social sectors and cross-sectors (National Disaster Management Agency, 2018).

Disasters cause various potential health problems for affected communities. This impact will be felt more severely by vulnerable population groups including: 1) Babies, toddlers and children; 2) Mothers who are pregnant or breastfeeding; 3) People with disabilities; and 4) elderly people. The Ministry of Health's Health Crisis Center data noted that there were 3,966 vulnerable groups after the Lombok earthquake, one of them in postpartum mothers who would be exposed to double susceptibility to serious mental disorders (Ministry of Health of the Republic of Indonesia, 2018).

Based on the results of interviews with several postpartum mothers, they said that they were still very traumatized by the earthquake, afraid and worried about the aftershocks and even the issue of the tsunami, so that it was difficult to rest, always awake even to take care of babies less optimally. Some mothers also said that they did not dare to let go of their babies and even left for a short time. The results of the preliminary study showed that the number of postpartum visits in all health centers in East Lombok Regency in July-October 2018 after the earthquake was 8,739 people while the data on the number of postpartum visits were mostly in JulyOctober 2018 after the earthquake, Kerongkong and Batu health centers totaling 445 postpartum mothers. The high number does not rule out the possibility of health problems that are also high in postpartum mothers both physically and psychologically. One of the psychological effects that occurred was postpartum depression after the earthquake (East Lombok Health Service, 2018).

Study conducted by Nasri et al. (2017) at Dr. R. Soedjono Selong East Lombok West Nusa Tenggara showed the prevalence of postpartum depression as much as $39.5 \%$. Most mothers who experience postpartum depression aged 20 to 35 years, have basic education, do not work, multipara, earn below the minimum wage and have less knowledge about the depression. Postpartum depression after the earthquake was caused by family loss, loss of residence, and loss of property. This situation requires that women in the postpartum period need to get social support from people around them so they can adjust to their new role as a mother. The lower the social support it receives, the higher the incidence of Postpartum Depression.

Based on data above, the authors are interested in conducting a study entitled "Determinants of postpartum post-earthquake depression in Lombok."

\footnotetext{
SUBJECTS AND METHOD

1. Study Design

This was analytic observational study with cross sectional approach, conducted in 25 villages in the working area of the Kerongkong and Batu health centers in East Lombok district in March to April 2019.
} 


\section{Population and Sample}

The population of this study was all postpartum mothers after the earthquake. Total 225 respondents was selected stratified random sampling from 25 villages and for each village were taken 9 subjects.

\section{Study Variables}

The dependent variable was postpartum depression. The independent variables were age, parity, education, employment, income, obstetric history, social support, stress coping, government support, the role of health personnel, and the level of loss.

\section{Operational Definitions of Study Variables}

Postpartum depression was a mood disorder experienced by post-earthquake mothers starting in the first 4 weeks after giving birth. The data collection was conducted using the Edinburgh Postnatal Depression Scale questionnaire (EPDS) with a continuous measurement scale and made dichotomous data when analyzed.

Age was the age of the mother when interviewed. Parity was the number of children ever born to a living mother. Education was a level of formal education that covers elementary, junior high, high school / vocational and tertiary levels which will affect the health behavior.

Occupation was an everyday activity carried out by the mothers. Income was the amount of money received by a husband or wife from a job.

Obstetrics was a history of labor during both normal / spontaneous, Induction and Secsio Cesarea. Social support was support from family, husband and relatives.

Stress coping was an attempt to change the behavior and the cognitive constantly to regulate specific internal or external demands that are valued as a burden or exceed the resources that an indi- vidual has. Government support was support from the central and regional governments in overcoming the risk of natural disasters after the Lombok earthquake. The role of health workers was health services during disasters and post-disaster.

The level of loss was the impact experienced by postpartum mothers after the earthquake including loss of family (death, injuries, and loss), damage to housing, and loss of property.

\section{Study Instruments}

Primary data was collected by questionnaires and the secondary data were obtained from the medical records of health centers.

\section{Data Analysis}

Data were analyzed by multilevel multiple logistic regression analysis with the Stata 13 program.

\section{Research Ethics}

This research includes information, approval, anonymity, confidentiality and ethical permission. Ethical feasibility in this study came from the Health Research Ethics Committee of the UNS FK with No: 436 / UN27.06 / KEPK / 2019.

\section{RESULTS}

\section{Univariate Analysis}

Table 1 showed that most mothers $<\mathbf{2 0}$ or $>35$ years old amount to 129 people (57.3\%), have a number of children $<2$ or $>$ 4 children as many as 114 people (50.7\%), low education of 96 people (42.7\%), no working of 113 people (50.2\%), low income of 121 people (53.8\%), no obstetric history of as 159 people (70.7\%), weak social support as many as 116 people (51.6), stress coping both as many as 128 (59.6), strong government support as many as 134 (59.6\%), the magnitude of the role of health workers was 147 (65.3\%), and the level of loss experienced after the earthquake was 122 people (54.2\%). 
Table 1. Sample characteristics

\begin{tabular}{|c|c|c|}
\hline Variable & $\mathbf{n}$ & $\%$ \\
\hline \multicolumn{3}{|l|}{ Age } \\
\hline 20-35 years & 96 & 42.7 \\
\hline$<20$ atau $>35$ years & 129 & $57 \cdot 3$ \\
\hline \multicolumn{3}{|l|}{ Parity } \\
\hline 2-4 children & 111 & 49.3 \\
\hline$<2$ dan $>4$ children & 114 & 50.7 \\
\hline \multicolumn{3}{|l|}{ Education } \\
\hline Low (<SHS/SMK) & 138 & 61.3 \\
\hline $\operatorname{High}(>$ SHS/SMK) & 87 & 38.7 \\
\hline \multicolumn{3}{|l|}{ Occupation } \\
\hline Not working & 112 & 49.8 \\
\hline Working & 113 & 50.2 \\
\hline \multicolumn{3}{|l|}{ Income } \\
\hline Low $(<\mathrm{Rp} 1,831,000)$ & 121 & 53.8 \\
\hline High ( $\geq$ Rp1,831,000) & 104 & 46.2 \\
\hline \multicolumn{3}{|l|}{ History of Obstetrics } \\
\hline No & 159 & 70.7 \\
\hline Yes & 66 & 29.3 \\
\hline \multicolumn{3}{|l|}{ Social Support } \\
\hline Weak & 116 & 51.6 \\
\hline Strong & 109 & 48.4 \\
\hline \multicolumn{3}{|l|}{ Stress coping } \\
\hline Poor & 97 & 43.1 \\
\hline Good & 128 & 56.9 \\
\hline \multicolumn{3}{|l|}{ Government support } \\
\hline Weak & 91 & 40.4 \\
\hline Strong & 134 & 59.6 \\
\hline \multicolumn{3}{|c|}{ Health personnel role } \\
\hline Small & 78 & 34.7 \\
\hline Big & 147 & 65.3 \\
\hline \multicolumn{3}{|l|}{ Feeling Loss Level } \\
\hline Small & 103 & 45.8 \\
\hline Big & 122 & 54.2 \\
\hline \multicolumn{3}{|c|}{ Postpartum Depression } \\
\hline No & 135 & 60.0 \\
\hline Yes & 90 & 40.0 \\
\hline
\end{tabular}

\section{Bivariate Analysis}

Table 2 showed that sujects with the age of $<20$ or $>35$ years $(\mathrm{OR}=3.75 ; \mathrm{p}<0.001)$, parity $<2$ or $>4$ children $(\mathrm{OR}=3.25 ; \mathrm{p}$ $<0.001)$, low education $(\mathrm{OR}=0.53 ; \mathrm{p}=$ o.029), low income $(\mathrm{OR}=0.38 \mathrm{p}=0.001)$, no obstetric history $(\mathrm{OR}=1.63 ; \mathrm{p}=$ 0.094), weak social support $(\mathrm{OR}=0.21 ; \mathrm{p}$ $<0.001)$, less stress coping $(\mathrm{OR}=0.14$; $\mathrm{p}$ $<0.001)$, weak government support $(\mathrm{OR}=$
$0.32 ; \mathrm{p}<0.001)$, the role of health personnel was small $(\mathrm{OR}=0.25 ; \mathrm{p}$ $<0.001$ ), and the level of loss was large $(\mathrm{OR}=11.84 ; \mathrm{p}<0.001)$ increasing the postpartum depression after the earthquake was statistically significant. Meanwhile the occupation did not have an effect on postpartum depression which was not statistically significant $(\mathrm{OR}=0.85$; $\mathrm{p}=0.549$ ). 
Journal of Maternal and Child Health (2019), 4(5): 380-391

https://doi.org/10.26911/thejmch.2019.04.05.12

Table 2. Bivariate analysis

\begin{tabular}{|c|c|c|c|c|c|c|c|c|}
\hline \multirow{3}{*}{ Variable } & \multicolumn{4}{|c|}{ Postpartum Depression } & \multirow{2}{*}{\multicolumn{2}{|c|}{ Total }} & \multirow{3}{*}{$\mathbf{O R}$} & \multirow{3}{*}{$\mathbf{p}$} \\
\hline & \multicolumn{2}{|c|}{ No } & \multicolumn{2}{|c|}{ Yes } & & & & \\
\hline & $\mathbf{n}$ & $\%$ & $\mathbf{n}$ & $\%$ & \multicolumn{2}{|c|}{ n $\%$} & & \\
\hline \multicolumn{9}{|l|}{ Age } \\
\hline 20-35 years & 74 & 771 & 22 & 22.9 & 96 & 100 & \multirow{2}{*}{$3 \cdot 75$} & \multirow[t]{2}{*}{$<0.001$} \\
\hline$<20$ atau $>35$ years & 61 & 47.3 & 68 & 52.7 & 129 & 100 & & \\
\hline \multicolumn{9}{|l|}{ Parity } \\
\hline 2-4 children & 82 & 73.9 & 29 & 26.1 & 111 & 100 & \multirow[t]{2}{*}{3.25} & \multirow[t]{3}{*}{$<0.001$} \\
\hline$<2$ dan $>4$ children & 53 & 46.5 & 61 & 53.5 & 114 & 100 & & \\
\hline \multicolumn{8}{|l|}{ Education } & \\
\hline Low (<SHS/SMK) & 75 & 54.3 & 63 & $45 \cdot 7$ & 138 & 100 & \multirow[t]{2}{*}{0.53} & \multirow[t]{2}{*}{0.029} \\
\hline $\operatorname{High}(>$ SHS/SMK) & 60 & 69 & 27 & 31 & 87 & 100 & & \\
\hline \multicolumn{9}{|l|}{ Occupation } \\
\hline Not working & 65 & 58 & 47 & 42 & 112 & 100 & \multirow[t]{2}{*}{0.85} & \multirow[t]{2}{*}{0.549} \\
\hline Working & 70 & 61.9 & 43 & 38.1 & 113 & 100 & & \\
\hline \multicolumn{9}{|l|}{ Income } \\
\hline Low $(<\mathrm{Rp} 1,831,000)$ & 60 & 49.6 & 61 & 50.4 & 121 & 100 & \multirow{2}{*}{0.38} & \multirow[t]{2}{*}{0.001} \\
\hline High ( $\geq$ Rp1,831,ooo) & 75 & 72.1 & 29 & 27.9 & 104 & 100 & & \\
\hline \multicolumn{9}{|l|}{ History of Obstetrics } \\
\hline No & 101 & 63.5 & 58 & 36.5 & 159 & 100 & \multirow[t]{2}{*}{1.63} & \multirow[t]{2}{*}{0.094} \\
\hline Yes & 34 & 51.5 & 32 & 48.5 & 66 & 100 & & \\
\hline \multicolumn{9}{|l|}{ Social Support } \\
\hline Weak & 50 & 43.1 & 66 & 56.9 & 116 & 100 & 0.21 & $<0.001$ \\
\hline Strong & 85 & 78 & 24 & 22 & 109 & 100 & & \\
\hline Stress coping & & & & & & & & \\
\hline Poor & 34 & 35.1 & 63 & 64.9 & 97 & 100 & 0.14 & $<0.001$ \\
\hline Good & 101 & 78.9 & 27 & 21.1 & 128 & 100 & & \\
\hline Government suppor & & & & & & & & \\
\hline Weak & 40 & 44 & 51 & 56 & 91 & 100 & 0.32 & $<0.001$ \\
\hline Strong & 95 & 70.9 & 39 & 29.1 & 134 & 100 & & \\
\hline Health personnel ro & & & & & & & & \\
\hline Small & 30 & 38.5 & 48 & 61.5 & 78 & 100 & 0.25 & $<0.001$ \\
\hline Big & 105 & 71.4 & 42 & 28.6 & 147 & 100 & & \\
\hline Feeling Loss Level & & & & & & & & \\
\hline Small & 90 & 87.4 & 13 & 12.6 & 103 & 100 & 11.84 & $<0.001$ \\
\hline Big & 45 & 36.9 & 77 & 63.1 & 122 & 100 & & \\
\hline
\end{tabular}

\section{Multilevel Analysis}

Table 4 showed that age $(b=1.79$; CI $95 \%=$ 2.85 up to $13.37 ; \mathrm{p}=0.001)$, parity $(\mathrm{b}=1.45$; CI 95\% $=0.37$ up to $2.53 ; \mathrm{p}=0.008)$, income $(b=-1.68$; CI $95 \%=-2.75$ up to -0.61 ; $\mathrm{p}=0.002)$, obstetric history $(\mathrm{b}=1.03$; CI $95 \%=-0.03$ up to $2.11 ; \mathrm{p}=0.059$ ), social support $(b=-1.62$; CI $95 \%=-2.76$ up to $0.48 ; \mathrm{p}=0.005)$, stress coping $(\mathrm{b}=-3.95$; CI $95 \%=-5.42$ up to $-2.47 ; \mathrm{p}<0.001$ ), government support $(\mathrm{b}=-1.26$; CI 95\% $=-2.34$ up to $-0.18 ; \mathrm{p}=0.022)$, the role of health personnel $(b=-2.06$; CI $95 \%=-3.29$ up to - o.83; $\mathrm{p}=0.001)$, and the level of loss $(\mathrm{b}=$ 2.69; CI $95 \%=1.46$ up to $3.92 ; \mathrm{p}<0.001$ ) had an effect on postpartum depression which was statistically significant. While the effect of education $(b=-0.60$; CI 95\%=1.63 up to $0.42 ; \mathrm{p}=0.250$ ), and employment $(b=0.57$; CI $95 \%=-0.44$ uo to 1.59 ; $\mathrm{p}=0.272$ ) have an effect on postpartum depression which was statistically insignificant. The village had a village contextual influence on the incidence of postpartum depression after the earthquake (ICC= 8.36\%). 
Tuhu et al./ Contextual Effect of Village on the Risk of Postpartum Depression after Earthquake

Table 3. Multilevel multiple logistic regression analysis

\begin{tabular}{|c|c|c|c|c|}
\hline \multirow[b]{2}{*}{ Variable } & \multirow{2}{*}{$\begin{array}{c}\text { Regression } \\
\text { Coefficient } \\
\text { (b) } \\
\end{array}$} & \multicolumn{2}{|c|}{ CI 95\% } & \multirow[b]{2}{*}{$\mathbf{p}$} \\
\hline & & Lower Limit & Upper Limit & \\
\hline \multicolumn{5}{|l|}{ Fixed-Effect } \\
\hline Age $(<20$ or $>35)$ & 1.79 & 0.73 & 2.85 & 0.001 \\
\hline Parity ( $<2$ and $>4$ children) & 1.45 & 0.37 & 2.53 & 0.008 \\
\hline Education (high $\geq \mathrm{HS}$ ) & -0.60 & -1.63 & 0.42 & 0.250 \\
\hline Employment (employed) & -0.57 & -0.44 & 1.59 & 0.272 \\
\hline Income (high $\geq R p 1.825 .000$ ) & -1.68 & -2.75 & $-0, .61$ & 0.002 \\
\hline History of Obstetrics (yes) & 1.03 & -0.03 & 2.11 & 0.059 \\
\hline Social Support (strong) & -1.62 & -2.76 & -0.48 & 0.005 \\
\hline Coping Stress (good) & -3.95 & -5.42 & -2.47 & $<0.001$ \\
\hline Government Support (strong) & -1.26 & -2.34 & -0.18 & 0.022 \\
\hline The Role of Health Personnel (strong) & -2.06 & -3.29 & -0.83 & 0.001 \\
\hline Level of Loss (strong) & 2.69 & 1.46 & 3.92 & $<0.001$ \\
\hline \multicolumn{5}{|l|}{ Random-Effect } \\
\hline Village Var (Constants) & 0.30 & 0.02 & 4.33 & \\
\hline \multicolumn{5}{|l|}{$\mathrm{N}$ Observation $=225$} \\
\hline \multicolumn{5}{|l|}{ Log likelihood = - 55.73} \\
\hline$p=0.060$ & & & & \\
\hline $\mathrm{ICC}=8.36 \%$ & & & & \\
\hline
\end{tabular}

\section{DISCUSSION}

\section{The Effect of Age on Postpartum Depression}

The results of this study showed that maternal age has a statistically significant influence on the incidence of postpartum depression.

This study was supported by Putriarsih et al. (2018), who found that there was a direct relationship between maternal age and postpartum depression which was statistically significant. Ages under 20 years old were thought to be able to experience obstacles in both physical and mental adjustment. While mothers who were above 35 years old were more at risk in conditions of pregnancy, childbirth, and also the puerperium period and have many responsibilities.

This was in line with Nasri et al. (2017), who stated that the high incidence of postpartum depression may also be influenced by differences in lack of experience with health problems or socioeconomic diseases.

\section{The Effect of Parity on Postpar- tum Depression}

The results of this study showed that parity has a statistically significant influence on the incidence of postpartum depression. Mothers with a number of children $<2$ or $>$ 4 can increase the incidence of postpartum depression by 1.45 than mothers who have 2 to 4 children $(b=1.45 ; \mathrm{CI} 95 \%=0.37$ to 2.53; $\mathrm{p}=0.008$ ).

The results of the study supported by Ria et al. (2015), who stated that there was a relationship between postpartum depression and parity, which would decrease by 1.24 times higher than mothers with $<2$ or $>4$ children. This was in line with the study of Badr (2018) showed that the number of children born either alive or dead would cause a level of mental stress in the mother. Because mothers were still caring for newborns and also caring for other children, because of this condition, it would cause the mother to feel tired, lack of sleep and lack of rest. According to Kerns et al. (2018), the more mothers give birth to children and were getting older, the lower 
the health of mothers and they were vulnerable to complications during labor that can lead to psychological problems.

\section{The Effect of Education on Post- partum Depression}

The results of the analysis showed that the effect of education was not statistically significant on the postpartum depression after the earthquake, but the results of this study showed that most mothers who experienced postpartum depression have low level of education (elementary and junior high school), meaning that higher maternal education would reduce postpartum depression by 0.6 times than mothers with low education.

The results of this study were supported by Stepanikova and Kukla (2017), which stated that women with low levels of education would increase the risk of depression after birth, low education was an indicator of a person's low social and economic issues. A low-educated mother would face difficulties in getting quality work (Kim and Dee, 2018).

Mental health problems were caused by low knowledge about post-disaster management, trauma healing, and the weak economic condition of the victims (Brewin et al., 2011)

\section{The Effect of Employment on Postpartum Depression}

The results showed that employment did not have a significant effect on the incidence of postpartum depression $(b=0.57$; CI95\% $=-0.44$ to $1.59 ; p=0.272$ ), but most mothers who experienced postpartum depression occurred in mothers who did not work (housewives) this mean that mothers who did not work can increase the incidence of postpartum depression by 0.57 greater than mothers who worked.

This study was supported by Nasri et al. (2017), who stated that mothers who did not work tend to experience postpartum depression and showed a high probability of affecting the psychological condition of the mother in facing her new role as a mother, staying at home as long as the husband went to work so that they were tired of having to do housework while caring for their baby. The amount of housework that mothers had to do result in difficulties in sharing time to take care of children and homework. In addition, there was a drastic change in the role of the mother who used to work.

\section{The Effect of Family Income on Postpartum Depression}

The results of the analysis showed that there was an effect of income and the incidence of postpartum depression after the earthquake. The results of this study indicated that high family income would reduce the incidence of postpartum depression by 1.68 times compared to mothers with low family income $(\mathrm{b}=-1.68$; CI $95 \%=-2.75$ up to $0.61 ; \mathrm{p}=0.002$ ).

According to Kun et al. (2009), low economic level in disaster victims was a factor that contributed to the psychological condition of disaster victims. Yuan et al. (2013), found that a low economy in disaster victims was associated with positive psychological development difficulties. Holland et al. (2011), also argued that families with low family incomes would have difficulty in accessing health services, transportation, and in fulfilling their baby's needs and self-efficacy about health tend to be lower in people with low income.

\section{The Effect of Obstetric History on Postpartum Depression}

The results of the analysis showed that the obstetric history had an influence on postpartum depression after the earthquake and the effect was statistically nearly significant. Mothers with obstetric history would increase the postpartum depression after the earthquake by 1.03 times higher com- 
pared to mothers who did not have an obstetric history, $(b=1.03$; CI $95 \%=-0.03$ to $2.11 ; \mathrm{p}=0.059$ ).

The results of this study were supported by Jannah (2019), who stated that postpartum mothers who did not have pregnancy complications reduce the risk of postpartum depression by 2.56 times higher compared to postpartum mothers who have pregnancy complications. Kettunen (2016), also argued that complicating labor was labor that experienced complications in which labor required several tools to give birth to children either by caesarean section, vacuum or forceps, which can make the body feel hurt and uncomfortable so that the mother experienced stress, therefore, labor complications can be a risk factor to be a predatory factor for postpartum depression.

\section{The Effect of Social Support on Postpartum Depression}

The results of the analysis showed that there was a significant influence between social support and postpartum depression. Mothers with strong social support would reduce postpartum depression after the earthquake 1.62 times higher than mothers who got weak social support $(b=-1.62$; CI $95 \%=-2.76$ to $-0.48 ; \mathrm{p}=0.005)$.

WHO (2013), stated that social support can come from family, friends, neighbors and health personnels. From various sources of social support, the most meaningful support for respondents was family support. The family was the closest party, providing support with security, being sincere, always accompanying the mother and not blaming. Social support, especially psychological support, was highly expected by mothers who were pregnant or giving birth because it was important to help the recovery process after labor (Negron et al., 2013).
Ria et al. (2015) stated that mothers who received strong family support were less likely to experience postpartum depression than mothers who received weak support because by giving motivation the mother felt more calm and comfortable. According to Reid and Taylor (2015), families were the main source of support for the health of postpartum women, families were the most powerful in providing support.

\section{The Effect of Stress Coping on Postpartum Depression}

The results of the analysis showed that stress coping has a significant influence on postpartum depression after the earthquake. Good mothers with stress coping would reduce the incidence of postpartum depression after the earthquake by 3.95 times $(b=-3.95$; CI 95\%= -5.42 to $-2.47 ; \mathrm{p}<0.001)$.

Gojani et al. (2018), stated that positive coping strategies would reduce the level of depression. Mothers who experienced psychological disorders mostly used problem focused coping compared with emotional focused coping. In line with the study of Jannah et al. (2019), it was reported that postpartum depression incidents were influenced by coping strategies.

\section{The Effect of Government Support on Postpartum Depression}

The results of the analysis showed that there was a significant effect of government support and the incidence of postpartum depression after the earthquake. Mothers with strong government support would influence to reduce the rate of postpartum depression after the earthquake $(b=-1.26$; CI 95\%= 2.34 to $-0.18 ; \mathrm{p}=0.022$ ).

Postpartum depression was affected due to lack of support from the government. The distribution and help distribution has been partially channeled both from government, private, and donors, but due to a lack of coordination between organiza- 
tions and agencies that have caused a lot of aid that were not distributed evenly, logistics has accumulated in one place, home improvement assistance funds that have not run out.

The National Disaster Management Agency (BNPB) (2018) stated that assistance from the government was partially running as it should. Funds for housing repairs to residents affected have been delayed because the technical instructions and implementation instructions have not been completed and the facilitators were still being formed and trained.

\section{The Effect of Health Personnel Role on Postpartum Depression}

This study showed that there was an effect of the role of health personnels and the incidence of postpartum depression after the earthquake. The results of this study indicated that mothers who got good role of health personnel would have an effect on decreasing postpartum depression after the earthquake by 2.06 times $(\mathrm{b}=-2.06$; CI $95 \%-3.29$ up to -0.83 ; $\mathrm{p}=0.001$ ).

The provision of inadequate health services was caused by other factors, namely damage to health facilities, limited number of types of drugs and medical devices so that the services provided were less optimal. The Ministry of Health Republic of Indonesia (2018), stated that postpartum mothers were vulnerable to face trauma and other psychological disorders that have an impact on the quality of life. In addition, the postpartum mother also lacked the availability of drugs, food and supplies for her child. Recovery was done through an approach by psychologists through trauma healing by empowering women to do many activities to divert their memories. Midwives and health personnels involved can fulfill the psychological needs of pregnant women as a support from health personnels.

\section{The Effect of Level of Loss on Postpartum Depression}

The results of the analysis showed that there was an effect of the rate of loss and the incidence of postpartum depression after the earthquake. The results of this study indicated that mothers who experienced loss would increase the incidence of postpartum depression after the earthquake by 2.69 times $(b=2.69$; CI $95 \%=1.46$ to 3.92 ; $\mathrm{p}<0.001$ ).

In this study, most of the mothers who experienced postpartum depression were affected by the level of loss due to the earthquake which resulted in a large part of the loss of residence due to destroyed or cracked houses, loss of property, even some family members suffered injuries and 2 of them were died from being hit by a house building.

This study was supported by Anwar et al. (2011), who showed that women who experienced loss/separation from family members would experience depression by 2.5 times higher than those who did not experience loss/separation from family members. Farooqui et al. (2017), also mentioned that separation from the husband's family and children due to disasters can increase the risk of PTSD. Depression can be triggered by intense stress, such as the death of family members or loved ones, divorce, childbirth and job loss.

\section{The Effect of Village on Postpar- tum Depression}

The results of this study indicate that there was a contextual effect of village on the incidence of postpartum depression (ICC $=$ 8.36\%). Village level ICC values indicated that the ICC value was as large as the benchmark $8-10 \%$ rule of thumb, so there was a contextual influence which in this study was the village.

The study was supported by Zhang et al. (2016), who reported that anxiety or de- 
pression was influenced by the village by taking into account the age group, gender, education, achievement and annual income.

Based on BNPB (2018), through regulation of BNPB No. 1/2012 stated that efforts have been carried out on CBDRM (community based disaster risk reduction) by developing the Resilient Village program by involving the community to play an active role in reviewing, analyzing, handling, monitoring, evaluating and reducing disaster risks in the village, especially by utilizing local resources to ensure sustainability.

\section{AUTHOR CONTRIBUTION}

Baiq Tuhu Abdiani as the main author in this study has a role in determining the theme and title of the study, determining the location and problems of study. Didik Tamtomo has a role in providing the theoretical basis of the problem of this study. Hanung Prasetya has a role in providing additional journal literacy in accordance with this study.

\section{FUNDING AND SPONSHORSHIP}

This study used the authors' independent costs.

\section{ACKNOWLEDGEMENT}

The authors would like to extend appreciation to postpartum mothers who were willing to become respondents and all parties involved during the study process.

\section{CONFLICT OF INTEREST}

There is no conflict of interest in this study.

\section{REFERENCE}

Ando S, Kuwabara H, Araki T, Kanehara A, Tanaka S, Morishima R, Kondo S, Kasai K (2011). Mental health problems in a community after the great
East Japan Earthquake in 2011. Harvard Review of Psychiatry. 25(1): 1528. doi: 10.1097/HRP.0000000000000124 .

Anwar J, Mpofu E, Matthews LR, Ahmed Farah Shadoul AF, Brock KE (2011). Reproductive health and access to healthcare facilities: risk factors for depression and anxiety in women with an earthquake experience. BMC Public Health. 11: 523. https://doi.org/10.1186/1471-2458-11-523.

Badan Meteorologi, Klimaktologi dan Geofisika (2018). Gempa Bumi. Ed (2). accesed from http://www.bmkg.go.id

The National Disaster Management Agency (BNPB) (2018). Laporan Harian tanggap darurat gempa bumi Lombok 29 Juli 2018. http://bnpb.go.id.

Badr L (2018). Infant Behavior and development is the effect of postpartum depression on mother- infant bonding universal? Journal of Infant Behavior and Development. 51: 15-23. https://doi.org/10.1016/j.infbeh.2018.02.003.

Brewin CR, Andrews B, Valentine JD (2000). Meta-analysis of risk factors for posttraumatic stress disorder in trauma-exposed adults. Journal of Clinical Health Psychology. 68(5): 748-766. http://dx.doi.org/10.1037/o022-006X.68.5.748.

Farooqui M, Quadri SA, Suriya SS, Adnan KM, Ovais Md, Sohail Z, Shoaib S, Tohid H, Hassan M (2017). Posttraumatic stress disorder: a serious pos-earthquake complication. Trends Psychiatry Psychoter. 39:2. http://dx.doi.org/10.1590/2237-6089-20160029.

Gojani GM, Kordi K, Asgharipour N, Esma $\mathrm{EH}$ (2018). Comparison of the effects of a positive reappraisal coping intervention and problem-solving skills training on depression during the 
waiting period of the result of intrauterine insemination treatment: a randomized control trial. International Journal Fertil Steril. 12(1): 13-18. doi: 10.220-74/ijfs.2018.5155.

Health Office East Lombok (2018). Data kunjungan nifas bulan Juli-Oktober pasca gempa Lombok. http://dinkes.lomboktimur.go.id

Holland ML, Kwang Yoo B, Kitzman H, Chaudron L, Szilagyi PG, Temkin GH (2011). Self-efficacy as a mediator between maternal depression and child hospitalizations in low-income urban families. Maternal and Child Health Journal. 15(7): 1011-1019. doi: 10.1007/s10995-010-0662-z.

Jannah AM, Budihastuti UR, Murti B (2019). Contextual effect of place of birth delivery on depression in Karanganyar, Central Java. Journal of Maternal and Child Health. 4(3): 212221. https://doi.org/10.26911/thejmch.2019.04.03.08.

Kerns AJL, Light A, Dalton V, Mcnamara B, Steinauer J, Kuppermann M (2018). Decision Satisfaction among women choosing a method of pregnancy termination in the setting of fetal anomalies and other pregnancy complications: a qualitative study. Science Direct. 101(10): 1859-1864. https://doi.org/10.1016/j.pec.2018.06.012.

Kettunen P, Koistinen Eeva, Hintikka J (2016). The Connections of pregnancy, delivery, and infant-related risk factors and negative life events on postpartum depression and their role in first and recurrent depression. Depression Research and Treatment. 2016:7. http://dx.doi.org/10.1155/2016/2514317.

Kim Y, Dee V (2018). Sociodemographic and obstetric factors related to symptoms of postpartum depression in hispanic women in rural California.
Journal of Obstetric and Gynecologic. 47 (1): 23-31. doi:10.1016/j.jogn.2017.11.012.

Kun P, Han S, Chen X, Yao L (2009). Prevalence and risk factors for posttraumatic stress disorder: a cross-sectional study among survivors of the Wenchuan 2008 Earthquake In China. Depress And Anxiety Journal. 26(12): 1134-1140. doi: 10.1002/da.20612.

Ministry of Health Republic of Indonesia. (2018). Jumlah korban gempa lombok. http://www.kemkes.go.id.

Nasri Z, Wibowo A, Ghozali A, Warsikki E (2017). Determinants factors of postpartum depression in East Lombok. Buletin Penelitian Sistem Kesehatan. 20(3), 89-95. http://dx.doi.org/10.22435/hsr.v2oi3.6137.89-95.

Negron R, Martin A, Almog M, Balbierz Amy, Howwel EA (2013). Social support during the postpartum period: mothers' views on needs, expectations, and mobilization of support. Maternal and Child Health Journal. 17(4): 616. https://doi.org/https://doi.org/10.1007/s10995-012-1037-4

Putriarsih R, Budihastuti UR, Murti B. (2018). Prevalence and determinants of postpartum depression in Sukoharjo District, Central Java. Journal of Maternal and Child Health. 03(01): 395-408. https://doi.org/10.26911/thejmch.2017.03.01.02

Reid KM, Taylor MG (2015). Social Support, stress, and maternal postpartum depression: a comparison of supportive relationships. Social Science Research. 54: 246-262. doi: 10.1016/j.ssresearch.-2015.08.009.

Ria, MB, Budihastuti UR, Sudiyanto A (2015). Risk factors of postpartum depression at Dr. Moewardi Hospital, Surakarta. Journal of Maternal and Child Health. 3(1): 81-90. https://- 
Tuhu et al./ Contextual Effect of Village on the Risk of Postpartum Depression after Earthquake

doi.org/10.26911/thejmch.2018.03.01. o8

Stepanikova I, Kukla L (2017). Is perceived discrimination in pregnancy prospectively linked to postpartum depression? exploring the role of education. Maternal and Child Health Journal. 21 (8): 1669-1677. https://doi.org/10.1007/s10995-016-2259-7.

World Health Organization (WHO) (2013). Building back better. sustainable mental health care after emergencies. Geneva. http://apps.who.int/iris/beattstream/10665/85377/1/978241564571e ng.pdf?ua $=1$
Yuan, KC, Yao ZR, Yu SZ, Dong ZX, Zhong YJ, Edwards JG, Edwards GD (2013). Prevalence and predictors of stress disorders following two earthquakes. International Journal Soci Psychiatry. 59: 525-530. https://doi.org/10.1177/0020764012453233\%oA

Zhang T, Shi W, Huang Z, Gao D, Guo Z, Liu J, Chongsuvivatwong V (2016). Influence of culture, residential segregation and socioeconomic development on rural elderly health-related quality of life in Guangxi, China. Health and Quality of Life Outcomes. 14(98). Doi 10.1186/s12955-016-0499-2. 